シンポジゥムうつ血性心不全の病態生理

（7）うつ血性心不全の二次性因子としての低蛋白血症の

出現機序とその意義

久留米大学医学部第三内科

横田泰司水口 宜信

戸嶋 裕德 木村 登

\title{
SYMPOSIUM ON PATHOPHYSIOLOGY OF CONGESTIVE HEART FAILURE \\ (7) PATHOGENESIS OF OCCURRENCE OF HYPOPROTEINEMIA IN PATIENTS WITH CONGESTIVE HEART FAILURE AND ITS SIGNIFICANCE
}

\author{
Yasushi Yokota, M.D., Takanobu Mrzuguchi, M.D., \\ Hironori Toshima, M.D., and Noboru Kimura M.D.
}

The Third Department of Internal Medicine, Kurume University School of Medicine

\section{はじめに}

血浆蛋白は膠質渗透圧の維持，ホルモンや薬物 輸送担体, 組織蛋白の供給源等の重要な役割を持 つためにその低下は生体にとつて種々の不利な状 態をつくり出す，とくにうつ血性心不全患者に発 生した低蛋白血症は，薬物効果や心筋代謝の面で 大きな影響を及ぼし本症の治療を困難にしその予 後に大い下関係すると考兄られる. 今回わたくし どもはこのように重要な意味をもつ心不全患者の 低蛋白血症について，その発生機序と心筋の蛋白 代謝に扎よぽす影響について検討したので報告す 万.

\section{I. 低蛋白血症の発生機序}

心不全患者に括ける低蛋白血症は総蛋白の低下 というょりも，A/G比の低下の形をとることが多 い.すなわち多くの症例で低アルブミン血症の形 をとるために，本研究では血清アルブミンを中心 としてその低下の機序を検討した。

\section{〔1〕対象および研究方法}

対象は肝機能，腎機能，内分泌機能に異常なく
血清アルブミン濃度正常の N Y H A I 度の患者 9 名 (先天性心臓病 2 名, 本態性高血王症 3 名, 神 経性循環無力症 4名）をcontrol として，心不全 患者34名（リウマチ性心臓病23名, 先天性心臓病 3 名, 虚血性心臟病 3 名, 高血王性心臟病 1 名, 収縮性心蔵炎 4 名）で，心不全患者はその血清了 ルブミン濃度により 3 群に分類した。すなわら血 清アルブミン濃度が $3.9 \mathrm{~g} / \mathrm{dl}$ 以上で正常值をしめ すものを 1 群， $3.9 \mathrm{~g} / \mathrm{dl}$ から $3.3 \mathrm{~g} / \mathrm{d}$ の間で軽度 ないし中等度の低下をしめすものを 2 群， $3.3 \mathrm{~g}$ / d1以下で高度の低下をしめするのを 3 群として各 群につき同時に次のよらな事項につき検討した。 すなわち低アルブミン血症の発生機序の可能性と して，（1）循環血浆量増大による希釈， 腸管へのアルブミンの漏出，（3） アルブミンの 合成障害，(4）アミノ酸のnet intake不足による 蛋白合成素材の不足を考觉て，（1） ${ }^{125}$ I-RISAの 希橎法による循環血浆量の測定，（2） ${ }^{51} \mathrm{Cr}$-RISA の䔬便への排泪率 ${ }^{12}$, (3) ${ }^{125}$ I-RISA投与後の尿 拉よび血中放射能のBerson ${ }^{2)}$, Sterling ${ }^{3)}$ らの方法 
による数学的解析による分解量の算出，（4） 4 日間の掑取食事中和よび瓷便中の窒素量測定によ るアミノ酸のnet intakeについて測定した。

\section{〔2〕結果および考案}

(1) 循環血浆量

循環血浆量の平均值於よび標準誤差は，control $47.3 \pm 1.8 \mathrm{ml} / \mathrm{kg}$, I 群 $53.1 \pm 2.8 \mathrm{ml} / \mathrm{kg}$, II 群 54.7 $\pm 2.6 \mathrm{ml} / \mathrm{kg}$, III群 $55.9 \pm 3.0 \mathrm{ml} / \mathrm{kg}$ で II 群および

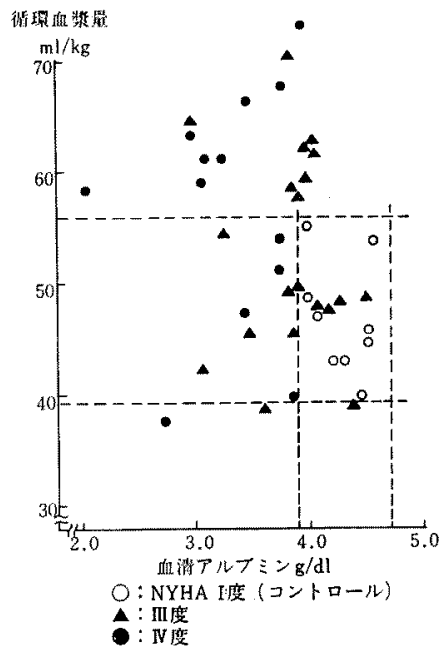

因 1. 血清フルブミン㩐度と循環血獎量

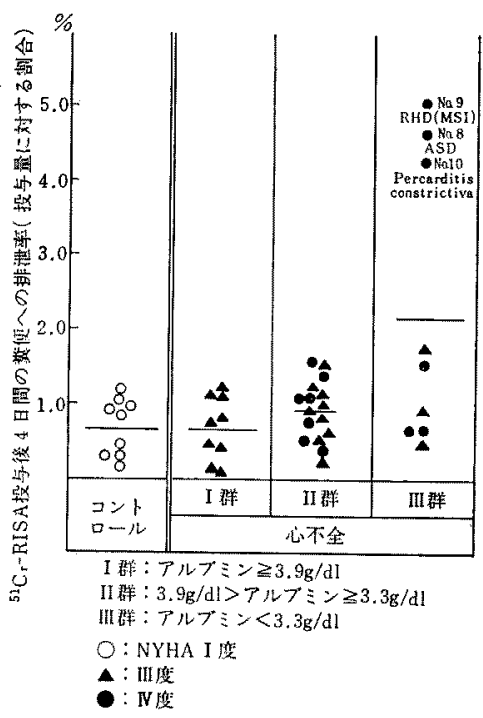

困2, 各群の便排㴓量
III群はcontrolk比べ有意の増大がみられた（ $\mathrm{p}<$ 0.05). したがつて低アルブミン血症の原因として この循環血㹺量增大に上る希积の可能性もある が，図1にみられるように血清アルブミン濃度と 循環血浆量との間には相関はみられず，血浆量の 増大による希粎では統一的には説明出来ない上う である.

（2）腸管へのアルブミンの排泄量

${ }^{51} \mathrm{Cr}-\mathrm{RISA}$ (約50 $\mu \mathrm{Ci}$ ）静注後 4 日間の糞便を集 めて，その放射能を測定し投与量に対する割合で 腸管への漏出の割合を検討した. 図 2 は各群の值 をしめするのであるが, control0.72士0.12\%，I 群0.74土0.15\%，II 群0.96士0.10\%でこの 3 者の 間には有意差はみられなかつた。すたこれらの值 はWaldmann")の基準に照し合わせても正常範囲 の排泄と考学られた.これに対して高度の低アル ブミン血症群である II群では 3 名が高い值をしめ し，腸管への異常な漏出が証明された．したがつ て，心不全患者において $3.3 \mathrm{~g} / \mathrm{dl}$ 以下をしめすよ らな高度の低アルブミン血症では，常に腸管への 漏出がその原因となり得る例のあることを考虑し なければならない，心疾患における蛋白漏出症と してはJimenez-Diazの報告以来収縮性心膜炎が多 く発表されてきたが，この疾患に特有なるのでは なく先天性心臓病や弁膜症等でも認められるが， その数は少なくないまた同じ高度の低アルブミ ン血症群である 3 群の中でも漏出の異常に大きい ものと正常域のものがみられるが，両者の間には 静脈圧, 右房平均圧, 心不全症状の経過年数, 肝機能等には差を認めなかつた。静脈圧は漏出 群ではすべて $160 \mathrm{mmH}_{2} \mathrm{O}$ 以上であつたが， 160 $\mathrm{mmH}_{2} \mathrm{O}$ 以上の患者でも漏出の認められないもの る多数あり血行動態的異常のみではこの漏出は説 明出来ない4)57.

（3）アルブミン分解量（合成量）

低アルブミン血症の次の可能性は，肝活打る フルブミンの合成障害があげられる．各群のアル ブミン分解量は control $250.8 \pm 5.0 \mathrm{mg} / \mathrm{kg} / \mathrm{day}, \mathrm{I}$ 群 $271.1 \pm 8.7 \mathrm{mg} / \mathrm{kg} /$ day, II 群 $213.9 \pm 4.6 \mathrm{mg} /$ 


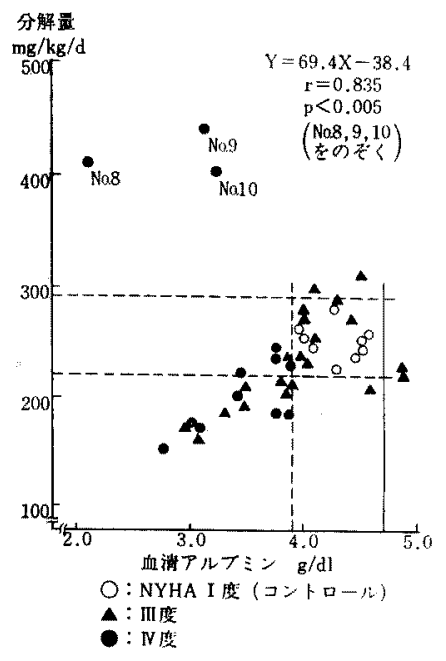

図 3．血清アルブミン濃度とアルブミン分解量

$\mathrm{kg} / \mathrm{day}$ ，群 $169.0 \pm 10.3 \mathrm{mg} / \mathrm{kg} /$ day（但し腸管へ の異常な漏出をみとめたNo. 8，9，10は除く)を しめし，II群はcontrolおよび I 群に有意に低下し ( $\mathrm{p}<0.005)$ ， III群はcontrol， I 群，II群のすべ てに対して有意の低下をしめした（ $\mathrm{p}<0.005)$. ここでこの検查期間中においては，血清アルブミ ン濃度は一定であつたので定常状態と考えられる ので，分解量は合成量に等しいと考えられる．そ こでこの分解量を合成量という言葉で和きかえて 考えると，I 群の合成量は controlと差を認めない が，II 群 III群の合成量有意の低下をしめすと考え られる. No. 8，9，10では腸管への漏出が大き いためにアルブミンの真の分解量（合成量）より 夕計算上大きな值が得ら机ると推定されるので， これらの例は除いた。図 3 はこのアルブミン分解 量（合成量）と血清アルブミン濃度の関係をしめ するのであるが，両者の間には高い相関が認めら れた（r=0.835， $\mathrm{p}<0.005)$ 。したがつて心不 全患者に批ける血清アルプミン濃度は，肝に求け るアルブミンの合成量と密接な関係を有し，合成 の低下が低アルプミン血症の主要な因子と考克ら れる. また図4にしめすようにアルブミン分解量 (合成量)は静脈圧とも逆相関をしめしており $(r=$ $-0.650, \mathrm{p}<0.005)$, これらの結果を考克合わ

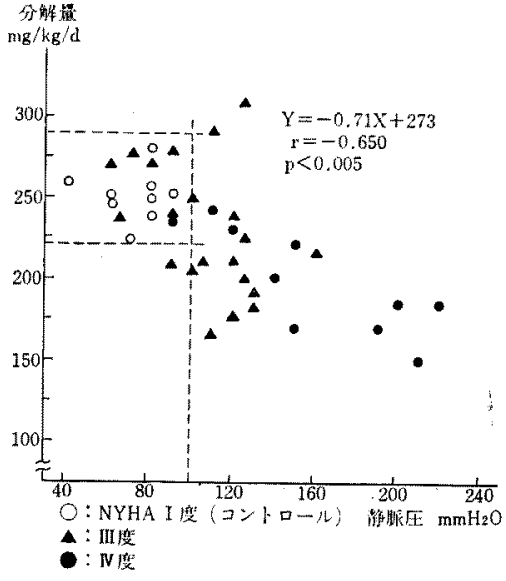

图 4.血清アルブミン分解量と静脈生

せると，心不全患者比ける低アルブミン血症の 多くは静脈圧上昇による朋のうつ血によつて肝に 拈けるアルブミンの合成が低下し，それが低アル ブミン血症の主要な因子となると推定される.

(4) $ア ミ$ 酸のnet intake

肝におけるアルブミン合成低下はらつ血肝によ る肝細胞の障害により招来される以外に摄取フミ ノ酸の不足や消化吸収障害によるnet intakeの不 足により蛋白合成素材 の 不足でも 発生するはず である。窒素のbalance studyの結果では，蛋白の net intakeはcontrol $1.62 \pm 0.09 \mathrm{~g} / \mathrm{kg} / \mathrm{day}, I$ 群 1.64 $\pm 0.07 \mathrm{~g} / \mathrm{kg} / \mathrm{day}$, II 群 $1.83 \pm 0.10 \mathrm{~g} / \mathrm{kg} / \mathrm{day}$, II 群 1.71 $\pm 0.29 \mathrm{~g} / \mathrm{kg} /$ dayで II 群，囵群では controlより高い 值をしぬすものもかなり認められ全体的には， 心不全患者で蛋白のnet intakeの不足はないよ らであつたしかしcontrol，I 群，II群ではすべ ての例が $1.25 \mathrm{~g} / \mathrm{kg} /$ dayであつたが，群では1.01 $\mathrm{g} / \mathrm{kg} / \mathrm{day} 1.04 \mathrm{~g} / \mathrm{kg} / \mathrm{day}$ と比較的低い值をしめした ものもあり，食䬦蛋白のnet intakeの不足がアル ブミン合成量の低下を起こす可能性は否定出来な いであるう。

〔3]小括

以上のようなデーターから心不全患者における 低アルブミン血症の発生機序として，

（1）肝に怙けるアルブミン合成障害が主因を 
なす。

（2）高度の低アルブミン血症では腸管への漏 出がその原因となる例妇みられる。

（3）アミノ酸つnet intake不足が関与すると 推定される例もある.

（4）偱環血浆量の増大による希釈では統一的 には説明出来ない。

\section{II. 低蛋白血症の心筋蛋白代謝に及ぼす影響}

心不全患者における低蛋白血症は種々の面で病 態を修飾し，心不全の進展に関与すると考兄られ るが，中でも心筋蛋白代謝に及注す影響は大きい であるら、そこでこの点を榆討するために動物実 験を行なつた。

\section{[1]対象および研究方法}

対象は 9 頭の雑種成犬を用いてその中の 4 頭に 大動脈閉塞不全を作製し，左室負荷の状態をつ くり（以下これを A I 犬群と記す），後う5頭を 正常犬群と乙てplasmapheresisとその後の低蛋白 食飼育で低蛋白血症の状態を作成して，その前後 の遊離アミノ酸の冠動静脈較差, 左室 $\max \mathrm{dp} / \mathrm{dt}$ について冠静脈洞カテーテル拉よび左室カテーテ 儿法を用いて測定した，さらに低蛋白血症の心筋 アクトミオシンへのアミノ酸のとり込みに対する 影響をみるために，屠殺 4 時間前にglycine-2-14C を $40 \mu \mathrm{Ci} / \mathrm{kg}$ の割に静注して左室掞よび骨格筋（大 腿筋）アクトミオンソをStraub-Feverの大沢，朝 倉変法で抽出しその放射能を測定した。

\section{〔2〕結果および考案}

（1）Plasmapheresis と低蛋白食後の血清蛋白

Plasmapheresis 2 2 週間の低蛋白食で血清蛋白 濃度は正常大群で $6.8 \pm 0.2 \mathrm{~g} / \mathrm{d}$ から $5.6 \pm 0.2$ $\mathrm{g} / \mathrm{dl}$ ， A I 犬群では $6.7 \pm 0.2 \mathrm{~g} / \mathrm{dl}$ から $5.4 \pm$ $0.17 \mathrm{~g} / \mathrm{dl}$ と同程度の低下をしめした。

(2)動脈血遊離アミノ酸

低蛋白血症作成前の動脈血遊離アミノ酸浱度 は，個々のアミノ酸によつてかなり異なつた值を しめすが正常大群とAＩ犬゙群の間には差はみられ なかつた，低蛋白血症作成後の変化としては正常 犬群ではタウリンの增加とアルギニンの低下がみ

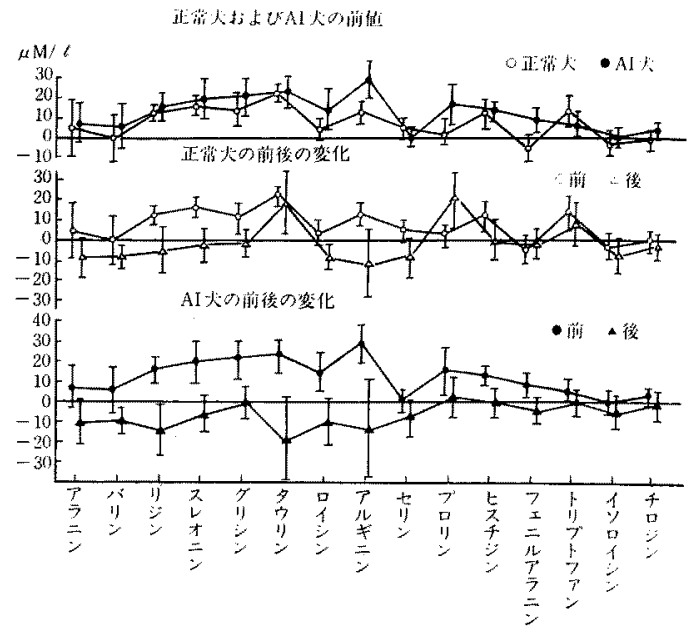

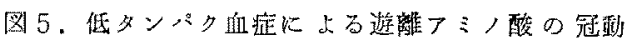
静脈較差の变化

られ，AＩ犬群ではタウリンの増加がみられた。 この変化の意味は不明であるがタウリンの場合に は生物学的に重要なアミノ酸ではないので心筋蛋 白代謝に牤よぼす影響は少なくないであるう。

(3)遊離

図 5 は各遊離アミノ酸の冠動静脈較差をしめす るのである．上段は正常犬抗よびＡＩ犬の低蛋白 血症作製前の值をしめすが，正常犬群ではアラニ ン，バリン，プロリン，フェニールアラニン，イ ソロイシン，チロジンの值は摄取されるものと遊 出するものがあり一定の傾向をしめさないが，そ の他は摂取傾向をしぬす。ＡＩ犬ではほとんどす べてのアミ，酸の摄取傾向がみられるが，やはり 個体差が大きく正常犬群との間には有意差はなか つた．中段は正常犬の前後の変化をしわすが，プ ロリン以外はすべて低蛋白血症作製後では摄取の 減少が遊出傾向が強くなつた。下段はAＩ犬の前 後の变化をしめすが，この場合も後で注遊出傾向 をしめすものが多かつた：しかしこれらの変化 は，正常犬特よびAＩ犬ともにばらつきが大きい ために有意の変化ではなかつた。

(4)アミノ酸の心筋アクトミオシンへのとり 込及 


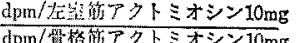

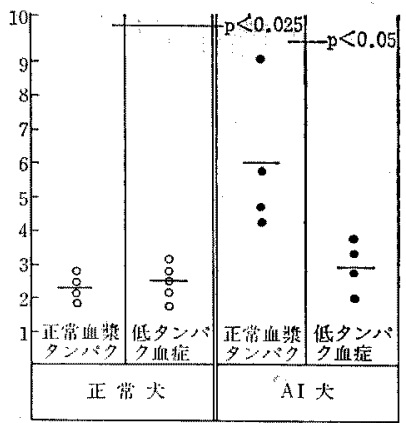

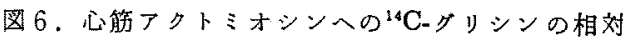

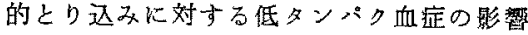

Glycine-2-14C 静注後抽出した心筋アクトミオシ ンの放射能を図 6 にしめす．この昜合投与量の誤 差や，各個体でアミノ酸プールが異なるた奶左 室筋アクトミオシンのdpmそのるのではばらつき が大きいために，その影響をなくすため骨格筋 飞対する左室筋アクトミオシンへのとり込みの比 (相対的とり込み)上してあらわした，正常血浆蛋 白時の值は既に発表したものであるが，正常犬の 平均值2.3に対して，AI犬では0.6とその增大が みられた．これ対して低蛋白血症時ではAI犬 でこの増大がみられずその值は2.9をしめした。 この結果は先にしめした低蛋白血症時に和ける心 筋からのアミノ酸の遊出傾向の增大と考克合わ好 ると非常に興味深いことで，血清蛋白正常で十分 な栄㽰素の供給されている時には，閉塞不全とい う心負荷に対して代償的なとり込及増大を打こし 心肥大がすみやかに行なわれるが，低蛋白血症時 でしかも十分な蛋白の供給されない時にはこの代 償的機点が十分得起こらないことが推定される。

(5)左室 $\max \mathrm{dp} / \mathrm{dt}$

低蛋白血症作製前後の左室 $\max \mathrm{np} / \mathrm{dt}$ は，正常 犬群では 3,280土73mmHg/secか 5 4,336士 354 $\mathrm{mmHg} / \mathrm{sec}$ と上昇した。 しかしこの増大は心収縮 力の増大によるものではなく，恐らく貧血等にと むなら心拍数の増大による 2 次的な変化と考光ら れる.これに対してAI犬群では，4515土 426 $\mathrm{mmHg} / \mathrm{sec}$ か 3,697 土 $559 \mathrm{mmHg} / \mathrm{sec}$ と有意で
はないが，低下の傾向をしめした。この左室 $\max$ $\mathrm{dp} / \mathrm{dt}$ の值には多くの因子が関係するために值に 心筋収縮能をしめすむのではないが，正常犬群に 比べAＩ犬群では低下傾向をしめしたことは興味 ある事実である，低蛋白血症時のこの心筋蛋白代 謝の変化と心機能との関保については，さらに多 くの検討が必要で告万う。

\section{〔3]小括}

正常犬拈よびA I 犬にplasmapheresisと低蛋白 食飼育で，低蛋白血症を作製し次の結果を得た。

（1）正常犬，AＩ犬ともに低蛋白血症作製後 では，心筋からアミ/酸の遊出傾向をしめす。

（2）AＩ犬では，正常血禁蛋白時にはアミ， 酸の心能へのとり込みが增大寸るが，低蛋白血症 時にはそのとりこみが拉こらない。

（3）左室 $\max \mathrm{dp} / \mathrm{dt}$ は低蛋白血证侍には低下 傾向をしぬす。

\section{おわりに}

以上心不全患者の低蛋白血症の発生機序と，そ の心筋蛋白代謝に対する影響についてわたくしど もの実験データーを中心として若干の考察を加兄 てきた。はじめに述べたように，心不全患者に発 生した低蛋白血症は多くの面で悪影響を及ぼし， 治撩を困難にすると考えられるので個ヶの症例に つきその発生原园を正確につきとめその対策が必 要であるら。

研究協力者：新居崎武俊，中村一規，上四集久, 太田勝利, 万江治夫，仮医神人

\section{文献}

1) T.A. Waldmann: Gastrointestinal protein loss demonstrated by ${ }^{\text {si }} \mathrm{Cr}$-labelled albumin. Lancet. 2: 121, 1961. -2) S.A. Berson, R.S. Yalow, S.S. Schreiber and J. Post: Tracer experiments with ${ }^{131}$ I-labeled human serum albumin. Distribution and degradation studies. J. clin. Invest. 32: 746, 1953. -3) K. Sterling: The turnover rate of serum albumin in man as measured by ${ }^{131} \mathrm{I}$ -tagged albumin. J. clin. Invest. 30: 1228, 1951. 4) P. Petersen and J. Hastrup: Protein-losing Enteropathy in constrictive pericarditis. Acta Med. Scand. 173: 401，1963. - -5) 村尾喾, 原田尚： シンボジゥム「蛋白漏出腸症」一蛋白漏出性胃晹 症と心疾蚛，日消誌，63：1，1966。 